\title{
Bioeconomic development in Europe and in the world
}

\author{
Aleksei Altoukhov ${ }^{1,2,3^{*}}$, Sergei Kashkin ${ }^{4}$, and Ekaterina Utkina $^{5}$ \\ ${ }^{1}$ Derzhavin Tambov State University, Laboratory for Network Analysis of Ecosystems, Tambov, \\ Russia \\ ${ }^{2}$ Lomonosov Moscow State University, 119991, Moscow, Leninskie gory, building 1 - 13, Russia \\ ${ }^{3}$ LLC Archangel Ecosystem, Moscow, Russia \\ ${ }^{4}$ Kutafin Moscow State Law University (MSAL), Integration and European Law Department, \\ 125993, Moscow, Sadovaya-Kudrinskaya st., 9, Russia \\ ${ }^{5}$ Lomonosov Moscow State University, Department of Innovation Economics, Department of \\ Environmental Economics, Economic Faculty, 119991, Moscow, Leninskie gory, building 1-46, \\ Russia
}

\begin{abstract}
Bioeconomy is one of the leading science directions at the present time; countries and international organizations around the world pay close attention to it. They are actively working on policies and strategies for the transition to a bioeconomy. Bioeconomy is based on advances in microbiology that can be used in various processes associated with the use of biological resources; it is changing consumer preferences by bringing a new understanding of resource constraints. Despite the fact that a great contribution has already been made to the science of bioeconomy, much in it still refers to promising scientific developments in such areas as biology, biomedicine, engineering, artificial intelligence, technology, chemistry, etc. This paper provides an overview of the current strategies of different countries in the development and implementation of bioeconomy. Purpose of the work: systematization of target indicators and identification of the most significant among them for different economies. The results of the study point to the need for an in-depth analysis of the challenges and opportunities the world faces on the road to bioeconomy. In addition, it is shown the need to develop common global criteria for assessing the bioeconomic development.
\end{abstract}

\section{Introduction}

Initially, the concept of bioeconomy emerged in the 1970s [1] as an attempt to efficiently combine biological, biophysical, institutional and social issues with general economic theory. But starting from about the 2000s, the concept of bioeconomy initially began to be defined as a mechanism for promoting sustainable development. Nowadays, there are linked two main ideas in the definition of bioeconomy [2-3]: the use of biotechnology and the use of renewable resources in production processes. Therefore,

\footnotetext{
* Corresponding author: aleksei.altoukhov@mail.ru
} 
bioeconomy can be defined as "an economy in which the basic building blocks for materials, chemicals and energy are derived from renewable biological resources" [4].

Growing environmental problems, especially those that are caused by human activities, require the strong control over production and consumer attitudes in order to protect natural resources and achieve sustainable development. The use of renewable resources can enable a society to maintain economic growth, limiting at the same time negative environmental impacts and conserving natural resources.

Adapting to a biotechnology-based economy requires significant changes in production patterns, widespread use of alternative sources of "clean" energy and renewable resources in production processes. Changing consumption patterns and convincing all stakeholders of the need to protect the environment is also important. The revision of outdated models and the involvement of society in need of sustainable development are as important in this process as the development of biotechnology.

The growing interest in bioeconomy as a way of ensuring sustainable global development is reflected in the development and implementation of a number of national and international strategies and documents [5]. In 2004, the Organization for Economic Cooperation and Development (OECD) published a document that emphasizes the need to develop a society based on the use of biological resources [6]. Later, in 2009, based on an analysis of various national bioeconomic strategies, the OECD published an agenda in this area [7]. In 2012, the European Union (EU) issued a directive to promote the implementation of bioeconomic strategies [8] and several countries have developed their own directives; in fact, at least 50 countries have already adopted or are in the process of adopting a bioeconomic strategy [9].

According to the definition that was given at the Global Bioeconomy Summit, bioeconomy is the knowledge-intensive production and use of biological resources, innovative biological processes and the principles of sustainable provision of goods and services in all sectors of the economy. In other words, we are talking about a necessary and highly beneficial for the whole world transition from an economy which is based on limited resources (fossil fuels) to a sustainable economy based on biotechnology (biofuels).

Bioeconomy implies that raw materials and key intermediates in the production process in many industries must be of biological origin. This will ensure the sustainability and environmental friendliness of industries and goods. As industrial raw materials it can be used biomass obtained from agricultural activities or biomass from extensive forest primary sources. Typically, many industries such as brewing, food, pulp and paper, and the bulk of the pharmaceutical industry (vaccines, prebiotics and probiotics) are biologically based, i.e. they are based on biological substances. The extension of the practice of using these biological resources to important industries that provide economic growth (for example, the fuel and energy sector) will help to improve the quality of products and the standard of living for the population. This refers to a significant reduction in air, water and soil pollution. This, of course, is an important economic and environmental aspect in satisfaction the needs of the constantly growing population of the planet.

An economy based on the use of biological resources is beneficial for all of us for the following reasons: reducing greenhouse gas emissions, improving environmental protection (including by reducing the volume of non-degradable and persistent pollutants), sustainable use of resources, the absence of secondary environmental pollution.

Bioeconomy is being developed as a new version of the relationship between production processes and the environment, with an emphasis on biotechnology and bioresources. It also includes ways to improve the quality of life of the population and to promote the development of the rural economy [6].

Thus, the researchers state that the bioeconomy offers great opportunities for improving welfare and global sustainable development [7-8]. Bioeconomic strategies seek to seize 
opportunities through tools such as: strategic science policy, incentives for innovation in the private sector, engaging consumer and environmental stakeholders who can benefit from products and public goods generated by innovations in bioeconomy.

\section{National and regional bioeconomic strategies}

The development of bioeconomy required the development of appropriate strategy documents, which concern, inter alia, biology, natural resources, science, ecology and many other areas. More than 45 countries around the world are already implementing bioeconomic development policies, and nine countries and regions (including the EU) have developed specific bioeconomic strategies. These strategies tend to represent a more holistic approach to promoting bioeconomic development than development policies. The strategies focus on the efficient use of the full potential of biological resources and processes in various sectors of the economy. The proposed measures also include supporting R\&D and stimulating demand for biotech products. A list of some of these strategies and a brief summary of them are presented below (see table 1).

In 2012, the EU issued a bioeconomic development strategy common to its members. In general, in the EU, the development of bioeconomy is carried out in the context and in conjunction with: research and innovation strategies, industrial strategies, green or blue economy strategies, strategies in the field of high technologies (biotechnology).

In addition, there are many initiatives in other countries and regions of the world. For example, in Canada, the provinces of Alberta, British Columbia and Ontario have adopted their own strategies of the bioeconomic development [10].

Table 1. Specialized bioeconomic strategies in selected countries and regions.

\begin{tabular}{|c|l|l|l|}
\hline $\begin{array}{c}\text { Country / } \\
\text { Region }\end{array}$ & Year & \multicolumn{1}{|c|}{ Strategy title } & \multicolumn{1}{|c|}{ Economic goals } \\
\hline $\begin{array}{c}\text { European } \\
\text { Union }\end{array}$ & 2018 & $\begin{array}{l}\text { A sustainable bioeconomy } \\
\text { for Europe: strengthening } \\
\text { the connection between } \\
\text { economy, society and the } \\
\text { environment [1] }\end{array}$ & $\begin{array}{l}\text { Economic growth, reducing of the } \\
\text { dependence on fossil fuels, } \\
\text { sustainable reindustrialization, } \\
\text { competitiveness }\end{array}$ \\
\hline $\begin{array}{c}\text { Great } \\
\text { Britain }\end{array}$ & 2018 & $\begin{array}{l}\text { Growing the bioeconomy: a } \\
\text { national bioeconomy } \\
\text { strategy to 2030 [12] }\end{array}$ & $\begin{array}{l}\text { To maximize the productivity and } \\
\text { potential of the Great Britain's } \\
\text { existing bioeconomy; to create the } \\
\text { right social and market conditions } \\
\text { for new bio-based products and } \\
\text { services; to benefit from world- } \\
\text { class research, development and } \\
\text { innovation base for the } \\
\text { development of the bioeconomy; } \\
\text { provide real and measurable } \\
\text { benefits to the economy. }\end{array}$ \\
\hline Ireland & 2018 & $\begin{array}{l}\text { National Policy Statement } \\
\text { on the Bioeconomy [13] }\end{array}$ & $\begin{array}{l}\text { Strengthening the development of } \\
\text { promising bio-products and } \\
\text { expanding relevant markets for } \\
\text { them, ensuring access to financing } \\
\text { at the EU level, as well as attracting } \\
\text { private investment. }\end{array}$ \\
\hline France & 2016 & $\begin{array}{l}\text { A Bioeconomy Strategy for } \\
\text { France [14] } \\
\text { economy, development of the agro- } \\
\text { industrial complex. }\end{array}$ \\
\hline Finland & 2014 & The Finnish Bioeconomy & \begin{tabular}{l} 
Economic growth, job creation, \\
\hline
\end{tabular} \\
\hline
\end{tabular}




\begin{tabular}{|c|c|c|c|}
\hline & & Strategy [15] & competitiveness, increased welfare. \\
\hline $\begin{array}{l}\text { Deutschla } \\
\text { nd }\end{array}$ & 2014 & $\begin{array}{l}\text { National Policy Strategy on } \\
\text { Bioeconomy [16]; } \\
\text { National Research Strategy } \\
\text { Bioeconomy } 2030[17]\end{array}$ & $\begin{array}{l}\text { Competitiveness, renewable raw } \\
\text { materials and energy from biomass, } \\
\text { economic growth. }\end{array}$ \\
\hline Austria & 2019 & $\begin{array}{l}\text { Bioeconomy - A Strategy } \\
\text { for Austria [18] }\end{array}$ & $\begin{array}{l}\text { The Bioeconomy Strategy aims to } \\
\text { become the cornerstone of the } \\
\text { Climate and Energy Strategy and to } \\
\text { promote the decarbonization of the } \\
\text { economic system. }\end{array}$ \\
\hline Sweden & 2012 & $\begin{array}{l}\text { Swedish Research and } \\
\text { Innovation - Strategy for a } \\
\text { Bio-Based Economy [19] }\end{array}$ & $\begin{array}{l}\text { Replacement of fossil raw } \\
\text { materials, smart products and more } \\
\text { intelligent use of raw materials, } \\
\text { changing consumption habits and } \\
\text { attitudes. }\end{array}$ \\
\hline Norway & 2016 & $\begin{array}{l}\text { The Government's } \\
\text { Bioeconomy Strategy - } \\
\text { Familiar resources - } \\
\text { undreamt of possibilities } \\
{[20]}\end{array}$ & $\begin{array}{l}\text { Reducing greenhouse gas } \\
\text { emissions. More efficient, } \\
\text { profitable and sustainable use of } \\
\text { renewable resources. }\end{array}$ \\
\hline Italy & 2019 & $\begin{array}{l}\text { BIT II - Bioeconomy in } \\
\text { Italy [21] }\end{array}$ & $\begin{array}{l}\text { Economic growth, more sustainable } \\
\text { value chains, smart specialization, } \\
\text { increased competitiveness. }\end{array}$ \\
\hline Spain & 2016 & $\begin{array}{l}\text { The Spanish Bioeconomy } \\
\text { Strategy: Horizon } 2030 \text { [22] }\end{array}$ & $\begin{array}{l}\text { Economic growth, job creation, } \\
\text { competitiveness, sustainable } \\
\text { manufacturing sectors, circular } \\
\text { economy. }\end{array}$ \\
\hline $\begin{array}{l}\text { Nether- } \\
\text { lands }\end{array}$ & 2018 & $\begin{array}{l}\text { The position of the } \\
\text { bioeconomy in the } \\
\text { Netherlands [23] }\end{array}$ & $\begin{array}{l}\text { Competitive and sustainable } \\
\text { economy. }\end{array}$ \\
\hline $\begin{array}{l}\text { South } \\
\text { Africa }\end{array}$ & 2013 & $\begin{array}{l}\text { The Bio-Economy Strategy } \\
{[24]}\end{array}$ & $\begin{array}{l}\text { Economic growth, job creation, } \\
\text { competitiveness. }\end{array}$ \\
\hline Malaysia & 2015 & $\begin{array}{l}\text { Bioeconomy transformation } \\
\text { program [25] }\end{array}$ & Economic growth, competitiveness. \\
\hline
\end{tabular}

In most countries of the world, the development of strategies in the field of bioeconomy is conditioned by the need to solve serious social and environmental problems of our time, including: global food security, climate change, sustainable resource management, etc. Bioeconomy is considered as a means of environmentally sound growth.

The goals underlying the promotion of the bioeconomy in different countries and regions correlate with their resource endowments, economic specialization and general level of socio-economic development. For example, oil importing countries with large biomass reserves promote bioeconomic development in order to achieve greater independence and generate income from the use of their biological resources. Industrialized countries with a large rural population and a high proportion of those employed in the extractive industries see bioeconomic development as a means of promoting rural development and social inclusion. Industrialized countries with fewer resources and fewer extractive industry jobs are paying more attention to opportunities arising from advances in bio sciences and biotechnology [26].

However, we should note that there is one important problem (flaw). Most strategic documents on bioeconomy designate its environmental and socio-economic aspects, but, as a rule, do not define specific, measurable goals and methods for their monitoring and evaluation. Most of the documents only point out that sustainability standards should be 
developed and agreed upon at the international level [27], without further specifying what exactly these standards should be.

Since bioeconomic strategies have been proposed as a way to overcome many global and national challenges (from climate action to rural income diversification), its ultimate goal was not to measure the bioeconomy as such, but to be sustainable. However, in our opinion, one of the ways to ensure the sustainability of bioeconomic strategies could be precisely linking its reporting with the internationally agreed concrete, measurable, sustainable development targets of the United Nations.

\section{Costs and benefits of bioeconomic policy measures}

It is important to bear in mind that bioeconomic activities do not always provide mutually beneficial results in both environmental and socio-economic terms. Since controversies are inevitable in any system, they must be properly tracked. This is necessary in order to minimize or ideally avoid causing indirect and unintended damage, including to the bioeconomy. The factors that influence the development of the bioeconomy, as well as the support measures used in the strategies of different countries, are quite diverse. In this study, we propose to group them into four main areas, which are listed below.

1) State policy.

Government intervention can affect the development of the bioeconomy both positively and negatively. The regulations that deal with food safety, environmental protection and health have a specific purpose. It is believed and expected that such regulations will enhance welfare and may even open up new development opportunities. On the other hand, food, health and environmental regulations can, on the contrary, reduce opportunities for development if they limit the availability of innovative and potentially useful products and services. Thus, the classic tensions and trade-offs between present and future benefits and costs can make it difficult to design and manage innovative bioeconomic strategies [4].

2) Food security.

The trade-offs that need to be made to jumpstart the global bioeconomy can lead to contentious issues regarding the use of biomass and food security. It is assumed that these contradictions can be largely resolved through innovations and the development of new production processes based on biomass and new technologies, as well as by increasing the efficiency of resource use and new opportunities in biochemical processes involving plants and microorganisms [28]. Nevertheless, a long process of coordinating positions and overcoming existing and future contradictions awaits us.

3) Economic effects for industry.

In response to concerns about the impact of the bioeconomy on human health and the environmental situation, certain rules and regulations have been adopted. Their implementation entails administrative costs for manufacturing companies, and if compliance with the rules causes delays in work, then there are opportunity cost too [29]. Therefore, it must be remembered that companies have an incentive to introduce new technology and products obtained on its basis only if there is a market in the broadest sense of the word, access to which will more than compensate all the costs that will need to be incurred to introduce such innovation. In turn, a potential market can exist if a new product is superior in quality or price, or if it complements the current one. If consumers want a new product, or expect it to be better, then they welcome innovations because of the opportunity to add value. Society as a whole can also benefit because more goods can be produced with the same amount of resources, or when the same amount of goods can be produced with fewer resources.

4) Impact on health and the environment. 
The production and consumption of new bioeconomic products can have positive or negative effects on human health and the environment. If in assessing the net benefits from the introduction of new technologies and principles, a negative impact is not excluded, then the introduction of restrictions or prohibitions to reduce it may be justified [29]. However, if all possible consequences are accounted for and positive net benefits are obtained, then the additional constraints should be considered unjustified in terms of social costs and benefits. In addition, it should be borne in mind that the impact of a particular new technology on human health and the environment may be less significant than the impact of the previous technology replaced by it. Some researchers argue that legal regulation can have a negative impact on investment (including in innovation) and slow down economic growth. Others point to the positive consequences of prudent regulation to prevent significant future damage. Moreover, it is not hard to see how some environmental and other regulations can even have a stimulating effect on the growth of economic efficiency at various levels. All of these conflicting opinions and probabilistic implications need to be considered when developing strategies and implementing bioeconomy.

Summarizing the above four points, it can be concluded that monitoring and assessing the impact of the bioeconomy on society, the economy and the environment is critical to ensure its sustainable development (i.e. to maintain or strengthen the environmental and social aspects of the law) Consequently, the purpose of monitoring and evaluation should be not only to measure progress towards the strategic goals of the bioeconomy as such, but to ensure its sustainability too.

Concluding this section, we add that it is advisable to develop regulatory norms in the field of bioeconomy based on advanced achievements in other branches of science, economics and law. First of all, we are talking about the use of modern technologies of artificial intelligence and Big Data. However, they should not be applied separately, independently of each other, but, on the contrary, on the basis of an appropriate unified legal platform that will unite and regulate their application to the problems of bioeconomic development. We proceed from the understanding that such a legal platform should represent uniform rules, standards, legal norms etc., in accordance with and on the basis of which will be carried out the interaction of participants and legal regulation, and will be provided the activities support using the latest digital technologies. Thus, a platform law for bioeconomy is a new legal mechanism that will regulate the implementation, application and management of modern information and "physical" technologies in it. Such platform bioeconomic law has yet to be formed.

\section{Conclusion}

In many countries and regions of the world, bioeconomy is gaining in importance and becoming an important benchmark in the field of sustainable development. Understanding the importance of sustainable development, both in production and in consumption, leads to a growing interest in the transition to a bioeconomy, in the use of renewable biological resources, as well as in the adoption of relevant regulations. According to a 2014 study, it was found that about $13 \%$ of world trade is in biological origin goods [26].

For the development of economic policy, which is based on the use of biological resources, important elements are the use of water, land and energy resources [28; 30]. Competition for limited resources creates conflicts between stakeholders and territorial entities. This, in turn, generates risks with significant consequences for people and the environment. In the future, this can lead to serious social inequalities mainly associated with access to water, food or energy resources, which requires a well-thought-out international regulatory framework [31] in the field of global bioeconomy. Thus, the transition to sustainable economic models is impossible without the involvement of all 
stakeholders and without recognition of the socio-technical changes accompanying the transition to a global bioeconomy.

This research paper is financially supported by the RFFI (Russian fund of fundamental research). Science project № 18-29-16150 “Artificial intelligence and robotics: comparative research of legal regulatory models in modern states, international organizations and integration associations".

\section{References}

1. N. Georgescu-Roegen, Review of Social \& Economy, 35, 361-375 (1977)

2. M. M. Bugge, T. Hansen, A. Klitkou, Sustainability, 8(7), 691 (2016)

3. D. D'Amato, N. Droste, B. Allen, M. Kettunen, K. Lähtinen, J. Korhonen, P. Leskinen, B. D. Matthies, A. Toppinen, JCP, 168, 716-734 (2017)

4. K. McCormick, N. Kautto, Sustainability, 5, 2589-2608 (2013)

5. T. Heimann, Bioeconomy and Sustainable Development Goals (SDGs): Does the Bioeconomy Support the Achievement of the SDGs? (American Geophysical Union, 2018)

6. OECD Biotechnology for Sustainable Growth and Development (OECD, 2004)

7. OECD The Bioeconomy to 2030. Designing a Policy Agenda (OECD, 2009)

8. European Commission (EC). Innovating for Sustainable Growth: a Bioeconomy for Europe (Luxembourg, Publication Office of the EO, 2012)

9. OECD Meeting Policy Challenges for a Sustainable Bioeconomy (OECD, 2018)

10. K. Birch, Sustainability, 8(10), 1007 (2016)

11. European Commission (EC). A sustainable bioeconomy for Europe: strengthening the connection between economy, society and the environment (Updated Bioeconomy Strategy) (Luxembourg, Publication Office of the EO, 2018)

12. Growing the bioeconomy: a national bioeconomy strategy to 2030 (London, Department for Business, Energy \& Industrial Strategy, 2018)

13. National Policy Statement on the Bioeconomy (Dublin, Department of the Taoiseach, 2018)

14. A Bioeconomy Strategy for France (Paris, Ministère del'Agriculture et de l'Alimentation, 2016)

15. Sustainable growth from bioeconomy. The Finnish Bioeconomy Strategy (Helsinki, Ministry of Employment and the Economy, Publishing Ltd, 2014)

16. National Policy Strategy on Bioeconomy (Berlin, Federal Ministry of Education and Research, 2014)

17. National Research Strategy Bioeconomy 2030 (Berlin/Bonn, Federal Ministry of Education and Research, 2011)

18. Bioeconomy - A Strategy for Austria (Federal Ministry, Republic of Austria, 2019)

19. Swedish Research and Innovation - Strategy for a Bio-Based Economy (Stockholm, FORMAS, 2012)

20. The Government's Bioeconomy Strategy - Familiar resources - undreamt of possibilities (Oslo, Ministry of Trade, Industry and Fisheries (Norway), 2016)

21. BIT II -Bioeconomy in Italy - A new bioeconomy strategy for a sustainable (Italy, Rome, Italian Presidency of Council of Ministers, 2019)

22. The Spanish Bioeconomy Strategy: Horizon 2030 (Government of Spain, 2016) 
23. The position of the bioeconomy in the Netherlands (The Hague, Ministry of Economic Affairs and Climate Policy (Netherlands), 2018)

24. The Bio-Economy Strategy (Pretoria, South Africa, DST, 2013)

25. Bioeconomy transformation program. Enriching the nation, securing the future. Annual report (MOSTI, Putrajaya, Malays, 2015)

26. B. El-Chichakli, J. von Braun, C. Lang, D. Barben, J. Philp, Nature, 535, 221-223 (2016)

27. How Sustainability Is Addressed in Official Bioeconomy Strategies at International, National and Regional Levels (Rome, FAO, 2016)

28. M.W. Rosegrant, C. Ringler, T. Zhu, S. Tokgoz, P. Bhandary, Agric. Econ., 44, 139150 (2013)

29. J.H.H. Wesseler, R.D. Socio-Economic Considerations in Biotechnology Regulation (NY, Springer, 2014)

30. T. Hertel, J. Steinbuks, U. Baldos, Agric. Econ., 44, 129-138 (2013)

31. A. Kotsakis, Transnational Environmental Law, 3, 127-147 (2014) 